\title{
HASIL PENGUJIAN SOFTWARE COMPUTERIZED ADAPTIVE TESTING (CAT) MATA PELAJARAN PENDIDIKAN AGAMA ISLAM (PAI) DALAM MEMBUAT REKAM MEDIK PEMBELAJARAN (RMP) UNTUK MENDIAGNOSIS KEMAMPUAN SISWA DI SEKOLAH
}

\author{
Winarno \\ Dosen Sekolab Tinggi Agama Islam (STAIN) Salatiga \\ Winarno5@yahoo,co,id
}

\begin{abstract}
This research aims at producing a Computerized Adaptive Testing (CAT) software Islamic religion education subject (CAT PAI) for the year 7 students of public junior high schoo and to see the results of CAT software in making rekam medik pembelajaran (RMP) to diagnose student's ability. This research used the research and development approach. The data was collected by doing observation and documentation. Analyzed to use quantitative descriptive technique.

The findings of the research shows the CAT can be developed web-based, and The CAT is able to in estimating student's ability correct be seen $R M P$. Overall, the CAT software can perform the tasks well in order to select test items and to measure student's ability from correlation value between ability estimation result (è) in CAT with Islamic religious education subjects enough tall that is 0,69 .
\end{abstract}

Keywords: Computerized Adaptive Testing (CAT), Islamic Religious Education (PAI), Rekam Medik Pembelajaran (RMP)

\begin{abstract}
Abstrak
Penelitian ini bertujuan membuat software Computerized Adaptive Testing untuk mata pelajaran Pendidikan Agama Islam (CAT PAI) jenjang SMP kelas VII dan melihat hasil pengujian software CAT PAI berupa rekam medik pembelajaran (RMP) dalam mendiagnosis kemampuan siswa. Penelitian ini menggunakan pendekatan Research and Development. Teknik pengambilan data menggunakan observasi dan dokumentasi. Teknik analisis menggunakan teknik deskriptif kuantitatif
\end{abstract}


Hasil penelitian menunjukkan: Software CAT PAI yang dikembangkan berbasis internet dan mampu mendiagnosis kemampuan siswa dengan tepat melalui RMP. Secara keseluruhan, Software CAT mampu melaksanakan tugas dengan baik untuk memilih butir tes dan mengukur kemampuan siswa dengan tepat berdasarkan korelasi antara hasil estimasi kemampuan pada CAT dengan nilai PAI siswa cukup tinggi yakni 0,69

Kata kunci: Computerized Adaptive Testing, Pendidikan Agama Islam (PAI), dan Rekam Medik Pembelajaran (RMP)

\section{Pendahuluan}

Komputerisasi penilaian individu saat ini lebih efisien dan akurat daripada penilaian menggunakan kertas dan pensil (pencil and paper test) (Wainer, 1990: 273). Salah satu prototype komputerisasi penilaian individu yang berkembang saat ini adalah Computerized Adaptive Testing (CAT). CAT adalah suatu metode pengujian atau evaluasi dengan menggunakan teknologi informasi yang bersifat adaptif. Adaptif berarti bahwa pemberian soal ujian berikutnya tergantung pada perilaku peserta ujian dalam menjawab soal sebelumnya sehingga ujian yang diberikan untuk setiap peserta dapat bersifat unik berdasarkan tingkat kemampuan masing-masing peserta.

Kelebihan-kelebihan yang ditawarkan oleh CAT antara lain: (1) CAT lebih efisien dan akurat dalam mengukur kemampuan siswa, CAT tidak memerlukan lembar jawaban karena skor dapat segera diketahui oleh siswa begitu tes telah dinyatakan selesai (Weiss, 2004: 72), (2) soal yang diberikan memiliki level kesukaran sesuai dengan kemampuan siswa, tidak terlalu susah ataupun terlalu mudah, (3) penilaian dapat dilakukan dengan segera sehingga dapat memberikan umpan balik yang cepat kepada siswa, (4) keamanan ujian dapat ditingkatkan. Rangkaian soal yang diberikan akan berbeda untuk setiap siswa sehingga soal yang akan muncul selanjutnya tidak dapat ditebak, Selain itu, bila jumlah soal banyak, kemungkinan munculnya soal yang sama lebih dari satu kali sangat kecil. Kerahasiaan soal pun dapat terjaga, karena soal tersimpan dalam suatu basis data dan hanya pembuat CAT yang membuat 
soal tersebut yang dapat mengupdatenya, dan (5) ujian dapat dipresentasikan melalui teks, grafik,audio, dan bahkan video klip,

CAT memerlukan: (1) bank soal, (2) prosedur pemilihan item awal, (3) prosedur pemilihan item selama pelaksanaan tes, (4) prosedur untuk mengakhiri tes, dan (5) estimasi kemampuan siswa (Masters \& Keeves, 1999: 130). Dalam prosedur pemilihan item awal diberikan item tes dengan tingkat kesukaran yang sedang. Prosedur pemilihan item tes selama pelaksanaan tes dalam CAT berdasarkan pada pola respon siswa yang akan dijadikan aturan untuk menentukan item tes berikutnya.

Pendidikan Agama Islam (PAI) merupakan mata pelajaran pada jenjang pendidikan dasar dan menengah yang dikembangkan dari ajaran-ajaran pokok (dasar) yang terdapat dalam agama Islam, sehingga PAI merupakan bagian yang tidak dapat dipisahkan dari ajaran Islam. PAI diberikan dengan mengikuti tuntunan bahwa agama diajarkan kepada manusia dengan visi untuk mewujudkan manusia yang bertakwa kepada Allah SWT dan berakhlak mulia, serta bertujuan untuk menghasilkan manusia yang jujur, adil, berbudi pekerti, etis, saling menghargai, disiplin, harmonis dan produktif, baik personal maupun sosial. PAI lebih menekankan bagaimana peserta didik mampu menguasai kajian keislaman tersebut sekaligus dapat mengamalkannya dalam kehidupan sehari-hari di tengahtengah masyarakat. Dengan demikian, PAI tidak hanya menekankan pada aspek kognitif saja, tetapi yang lebih penting adalah pada aspek afektif dan psikomotornya

CAT bisa diterapkan pada semua mata pelajaran di sekolah termasuk mata pelajaran Pendidikan Agama Islam (PAI). Dengan CAT pada mata pelajaran PAI (CAT PAI) maka dapat dilihat hasil rekam medik pembelajaran (RMP) sebagai output dari CAT yang sangat bermanfaat bagi guru untuk mendiagnosis kemampuan siswa selama pelaksanaan proses belajar mengajar.

Penelitian ini difokuskan untuk menjawab dua permasalahan: (1) bagaimana mengembangkan software (CAT PAI) kelas VII jenjang SMP dalam membuat rekam medik pembelajaran (RMP)? (2) bagaimanakah kemampuan CAT PAI dalam mengestimasi kemampuan siswa dengan akurat dan tepat? 


\section{Computerized Adaptive Testing (CAT)}

Adaptive testing adalah suatu tes yang menyesuaikan kemampuan peserta (Lord, 1980: 20). Menurut Wainer (1990: 105) adaptive testing merupakan tes yang diselenggarakan bagi siswa dengan pertanyaanpertanyaan/item-itemnya ditentukan berdasarkan jawaban (respons) awal peserta. Penyelenggaraan tes adaptif berbeda dengan paper and pencil test (PP test). Pada PP tes seluruh siswa akan diberikan soal dan jumlah soal yang tetap atau sama, sedangkan pada tes adaptif setiap peserta akan diberikan soal yang berbeda-beda, Soalsoal pada tes adaptif menyesuaikan dengan ke-mam-puan masing-masing siswa.

Prinsip Computerized Adaptive Testing (CAT) adalah sebagai berikut:

1. Membangun Item bank

Item bank dalam CAT umumnya menggunakan Item Response Theory (IRT) (Lord, 1980: 15). Dalam IRT memiliki karakteristik diantaranya: (a) IRT tidak berdasarkan grup dependent, (b) skor siswa dideskripsikan bukan test dependent, dan (c) model ini menekankan pada tingkat butir soal bukan tes, (Hambleton dan Swaminathan, 1985: 11). Item bank dalam penelitian ini adalah bank soal mata pelajaran Pendidikan Agama Islam (PAI) kelas VII jenjang pendidikan sekolah menegah pertama (SMP)

2. Prosedur Pemilihan Item Awal (Starting Rules)

Dalam prosedur pemilihan item awal, siswa akan diberi satu set soal yang memenuhi spesifikasi rancangan tes (kisi-kisi) dan biasanya sesuai dengan tingkat kemampuan setiap individu. Tes dimulai dengan soal-soal yang tidak terlalu sukar atau tidak terlalu mudah. Performance awal mengenai kemampuan awal peserta tidak ada, maka CAT dapat dimulai dengan memilih butir soal dengan tingkat kesukaran yang sedang (Mills, 1999: 123), artinya dalam CAT untuk pemilihan awal soal diambil soal-soal yang tidak terlalu sulit atau tidak terlalu mudah (kategori sedang) karena untuk siswa yang memiliki kemampuan ekstrim tidak terlalu lama mencapai estimasi kemampuannya, Setiap siswa menjawab soal dan komputer akan memberikan skor kemampuan (è). Jawaban terhadap soal tersebut dan akan 
menentukan soal yang akan ditampilkan oleh komputer selanjutnya. Setiap menjawab soal dengan benar, siswa akan diberi soal yang lebih sukar. Sebaliknya, bila menjawab salah, komputer akan memilihkan soal yang lebih mudah.

3. Prosedur Pemilihan Item Selama Pelaksanaan Tes Menggunakan Metode Pohon Segitiga Keputusan

Dalam CAT menggunakan metode pohon segitiga keputusan (triangle decision tree method) pada prosedur pemilihan item selama pelaksanaan tes menggunakan model teori respons butir (IRT) tiga parameter (3P) yang terdiri dari tingkat kesukaran, daya beda, dan tingkat menebak (guessing) yang diperoleh dan disimpan di sebuah bank soal (Phankokkruad, 2008: 656). Sebuah pohon segitiga keputusan adalah model keputusan yang berbentuk grafik. Sebuah simpul menunjukkan parameter tes sebaliknya ranting manunjukkan target paramater tes berikutnya. Setiap simpul hanya ada dua cabang, untuk simpul anak cabang berisi tiga parameter IRT. Cabang yang keluar dari titik ada dua yaitu cabang ke arah kiri dan cabang kearah kanan. Arah cabang akan ke kanan bila siswa menjawab pertanyaan dengan benar dan arah cabang akan ke ke kiri bila siswa menjawab pertanyaan item yang salah.

4. Prosedur Untuk Mengakhiri Tes (Stopping Rules)

Keputusan mengenai kapan harus menghentikan tes CAT adalah elemen yang paling penting. Jika tes ini terlalu pendek, maka perkiraan kemampuan siswa tidak akurat. Jika tes ini terlalu panjang, maka banyak waktu dan beaya yang terbuang dan menyebabkan hasil tes tidak valid, Tes CAT berhenti bila: (a) item bank telah habis, dan (b) kemampuan (è) siswa konvergen nilai tertentu.

5. Estimasi Kemampuan Siswa

Langkah terakhir dalam pengembangan CAT adalah estimasi kemampuan siswa. Salah satu metode yang bisa digunakan dalam mencari estimasi kemampuan siswa dalam CAT adalah menggunakan metode Maximum Likelihood (MLE). Bila seorang siswa dengan tingkat kemampuan è menjawab tes yang berisi sebanyak $n$ butir soal pilihan ganda dengan parameter butir 
(tingkat kesukaran, daya beda dan guessing) yang sudah diketahui dan sudah diestimasi sebelumnya maka peluang bersama dari siswa adalah $p\left(U_{1}, U_{2}, U_{3} \ldots U_{n} \mid \theta\right)$. Dalam praktik pengukuran maka $u_{1}, u_{2}, u_{3} \ldots . u_{n}$ adalah jawaban dari siswa, $u_{i}=1$ jika jawaban siswa adalah benar dan $\boldsymbol{u}_{i}=0$ maka jawaban siswa yang salah. Jika asumsi independensi lokal dipenuhi maka fungsi kemungkinan maximum likelihood adalah

$$
=\prod_{i=1}^{n} P_{i}(\theta)^{u_{i}} Q_{i}(\theta)^{1-u_{i}} \text { dimana } \mathrm{i}=1,2,3, \ldots \text { n untuk }-\sim<\mathrm{e}<\sim \ldots .
$$

\section{Pendidikan Agama Islam (PAI)}

Pendidikan Agama Islam adalah upaya sadar dan terencana dalam menyiapkan peserta didik untuk mengenal, memahami, menghayati, hingga mengimani ajaran agama Islam, dibarengi dengan tuntutan untuk menghormati penganut agama lain dalam hubungannya dengan kerukunan antar umat beragama sehingga terwujud kesatuan dan persatuan bangsa (Majid, 2005: 130). Pendidikan Agama Islam diberikan dengan mengikuti tuntunan bahwa agama diajarkan kepada manusia dengan visi untuk mewujudkan manusia yang bertakwa kepada Allah SWT dan berakhlak mulia, serta bertujuan untuk menghasilkan manusia yang jujur, adil, berbudi pekerti, etis, saling menghargai, disiplin, harmonis dan produktif, baik personal maupun sosial.

Tuntutan ini mendorong dikembangkannya standar kompetesi sesuai dengan jenjang persekolahan yang secara nasional ditandai dengan ciri-ciri:(1) lebih menitik beratkan pencapaian kompetensi secata utuh selain penguasaaan materi; (2) mengakomodasikan keragaman kebutuhan dan sumber daya pendidikan yang tersedia; dan (3) memberiklan kebebasan yang lebih luas kepada pendidik di lapangan untuk mengembangkan strategi dan program pembelajaran seauai dengan kebutuhan dan ketersedian sumber daya pendidikan. 
Pendidikan Agama Islam diharapkan menghasilkan manusia yang selalu berupaya menyempurnakan iman, takwa, dan akhlak, serta aktif membangun peradaban dan keharmonisan kehidupan, khususnya dalam memajukan peradaban bangsa yang bermartabat. Manusia seperti itu diharapkan tangguh dalam menghadapi tantangan, hambatan, dan perubahan yang muncul dalam pergaulan masyarakat baik dalam lingkup lokal, nasional, regional maupun global.

Pendidikan Agama Islam di SMP/MTs bertujuan untuk: (1) menumbuhkembangkan akidah melalui pemberian, pemupukan, dan pengembangan pengetahuan, penghayatan, pengamalan, pembiasaan, serta pengalaman peserta didik tentang agama Islam sehingga menjadi manusia muslim yang terus berkembang keimanan dan ketakwaannya kepada Allah SWT; dan (2) mewujudkan manuasia Indonesia yang taat beragama dan berakhlak mulia yaitu manusia yang berpengetahuan, rajin beribadah, cerdas, produktif, jujur, adil, etis, berdisiplin, bertoleransi (tasamuh), menjaga keharmonisan secara personal dan sosial serta mengembangkan budaya agama dalam komunitas sekolah.

Ruang lingkup Pendidikan Agama Islam meliputi aspek-aspek sebagai berikut: (1) Al Qur'an dan Hadits, (2) Aqidah, (3) Akhlak, (4) Fiqih, dan (5) Tarikh dan Kebudayaan Islam. Pendidikan Agama Islam menekankan keseimbangan, keselarasan, dan keserasian antara hubungan manusia dengan Allah SWT, hubungan manusia dengan sesama manusia, hubungan manusia dengan diri sendiri, dan hubungan manusia dengan alam sekitarnya.

Standar Kompetensi dan Kompetensi Dasar mata pelajaran Pendidikan Agama Islam (PAI) kelas VII jenjang pendidikan sekolah menegah pertama (SMP) seperti Tabel 1 dan Tabel 2 berikut. 


\section{Tabel 1.}

Standar Kompetensi dan Kompetensi Dasar PAI Kelas VII, Semester I

\author{
Standar Kompetensi \\ Al-Qur'an \\ 1. Menerapkan Hukum \\ bacaan "Al" Syamsiyah \\ dan "Al"Qomariyah
}

\section{Aqidah}

2. Meningkatkan keimanan kepada Allah SWT melalui pemahaman sifatsifatNya

3. Memahami Asmaul Husna

\section{Akhlak \\ 4. Membiasakan perilaku terpuji}

\section{Fiqih}

5. Memahami ketentuanketentuan thaharah (bersuci)

6. Memahami tatacara shalat

7. Memahami tatacara shalat jamaah dan munfarid (sendiri)

\section{Tarikh dan kebudayaan} Islam

8. Memahami sejarah Nabi Muhammad SAW

\section{Kompetensi Dasar}

1.1 Menjelaskan hukum bacaan bacaan "Al" Syamsiyah dan "Al"Qomariyah

1.2 Membedakan hukum bacaan bacaan "Al" Syamsiyah dan "Al"Qomariyah

1.3 Menerapkan bacaan bacaan "Al" Syamsiyah dan "Al"Qomariyah dalam bacaan surat-surat Al-Qur'an dengan benar

2.1 Membaca ayat-ayat Al-Qur'an yang berkaitan dengan sifat-sifat Allah

2.2 Menyebutkan arti ayat-ayat Al-Qur'an yang berkaitan dengan sifat-sifat Allah SWT

2.3 Menunjukkan tanda-tanda adanya Allah SWT

2.4 Menampilkan perilaku sebagai cermin keyakinan akan sifat-sifat Allah SWT

3.1 Menyebutkan arti ayat-ayat Al-Qur'an yang berkaitan dengan 10 Asmaul Husna

3.2 Mengamalkan isi kandungan 10 Asmaul Husna

4.1 Menjelaskan pengertian tawadhu, ta'at, qana'ah dan sabar

4.2 Menampilkan contoh-contoh perilaku tawadhu, ta'at, qana'ah dan sabar

4.3 Membiasakan perilaku tawadhu, ta'at, qana'ah dan sabar

5.1 Menjelaskan ketentuan-ketentuan mandi wajib

5.2 Menjelaskan perbedaan hadas dan najis

6.1 Menjelaskan ketentuan-ketentuan shalat wajib

6.2 Memperaktikkan shalat wajib

7.1 Menjelaskan pengertian shalat jama'ah dan munfarid

7.2 Memperaktikkan shalat jama'ah dan shalat munfarid

8.1 Menjelaskan sejarah Nabi Muhammad SAW

8.2 Menjelaskan misi nabi Muhammad untuk semua manusia dan bangsa 


\section{Tabel 2.}

\section{Standar Kompetensi dan Kompetensi Dasar PAI Kelas VII, Semester II}

\begin{tabular}{|c|c|}
\hline Standar Kompetensi & Kompetensi Dasar \\
\hline \multicolumn{2}{|l|}{ Al-Qur'an } \\
\hline \multirow{3}{*}{$\begin{array}{l}\text { 1. Menerapkan hukum } \\
\text { bacaan nun mati/tanwin } \\
\text { dan mim mati }\end{array}$} & $\begin{array}{l}\text { 1.1 Menjelaskan hukum bacaan nun } \\
\text { mati/tanwin dan mim mati }\end{array}$ \\
\hline & $\begin{array}{l}\text { 1.2 Membedakan hukum bacaan nun } \\
\text { mati/tanwin dan mim mati }\end{array}$ \\
\hline & $\begin{array}{l}\text { 1.3 Menerapkan hukum bacaan nun } \\
\text { mati/tanwin dan mim mati dalam bacaan } \\
\text { surat-surat Al-Qur'an dengan benar. }\end{array}$ \\
\hline \multicolumn{2}{|r|}{ 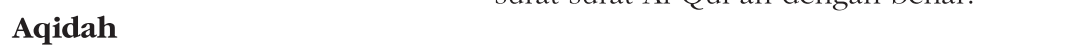 } \\
\hline 10. Meningkatkan keir & 10.1 Menjelaskan arti beriman kepada Malaikat \\
\hline \multicolumn{2}{|l|}{ Akhlak } \\
\hline \multirow[t]{3}{*}{$\begin{array}{l}\text { 11. Membiasakan perilaku } \\
\text { terpuji }\end{array}$} & $\begin{array}{l}\text { 11.1 Menjelaskan arti kerja keras, tekun, ulet } \\
\text { dan teliti }\end{array}$ \\
\hline & $\begin{array}{l}\text { 11.2 Menampilkan contoh perilaku kerja keras, } \\
\text { tekun, ulet, dan teliti }\end{array}$ \\
\hline & $\begin{array}{l}\text { 11.3 Membiasakan perilaku kerja keras, ulet, } \\
\text { tekun dan teliti }\end{array}$ \\
\hline \multicolumn{2}{|r|}{ - w } \\
\hline \multirow[t]{2}{*}{$\begin{array}{l}\text { 12. Memahami tatacara } \\
\text { shalat Jum'at }\end{array}$} & $\begin{array}{l}\text { 12.1 Menjelaskan ketentuan-ketentuan shalat } \\
\text { jum'at }\end{array}$ \\
\hline & 12.2 Mempraktekkan shalat jum'at \\
\hline 13. Memahami tatacara & 13.1 Menjelaskan shalat jama' dan qashar \\
\hline shalat jama' dan qashar & 13.2 Mempraktekkan shalat jama' dan qashar \\
\hline \multicolumn{2}{|l|}{$\begin{array}{l}\text { Tarikh dan Kebudayaan } \\
\text { Islam }\end{array}$} \\
\hline \multirow{5}{*}{$\begin{array}{l}\text { 14. Memahami sejarah Nabi } \\
\text { Muhammad SAW }\end{array}$} & 14.1 Menjelaskan misi Nabi Muhammad SAW \\
\hline & $\begin{array}{l}\text { untuk menyempurnakan akhlak, } \\
\text { membangun manusia mulia dan } \\
\text { bermanfaat }\end{array}$ \\
\hline & 14.2 Menjelaskan misi Nabi Muhammad SAW \\
\hline & $\begin{array}{l}\text { pebaga1 rahmat bag1 alam semesta, } \\
\text { kembawa kedamaian, kesejahteraan, dan } \\
\text { kemajuan masyarakat }\end{array}$ \\
\hline & $\begin{array}{l}\text { 14.3 Meneladani perjuangan Nabi dan para } \\
\text { Sahabat dalam menghadapi masyarakat } \\
\text { Makkah }\end{array}$ \\
\hline
\end{tabular}

\section{Rekam Medik Pembelajaran (RMP)}

Menurut Kamus Besar Bahasa Indonesia (KBBI) arti kata rekam adalah bekas atau kesan dari sesuatu yg dituliskan, arti kata pembelajaran adalah proses, cara, perbuatan menjadikan orang hidup belajar. Jadi rekam medik pembelajaran (RMP) adalah kesan yang 
ditulis mengenai hasil kemampuan siswa selama proses belajar mengajar. Hasil kemampuan siswa dilihat melalui hasil respons (benar atau salah) dalam menjawab soal mata pelajaran Pendidikan Agama Islam (PAI) kelas VII jenjang pendidikan sekolah menegah pertama (SMP) yang berdasar standar kompetensi (SK), kompetensi dasar (KD), indikator, tingkat kesukaran, daya beda, tingkat menebak, waktu mengerjakan, dan skor akhir.

\section{Metode Penelitian}

Jenis penelitian ini menggunakan Research and Development (R\&D), Dalam pengembangan software CAT mata pelajaran Pendidikan Agama Islam (PAI) kelas VII jenjang pendidikan sekolah menegah pertama (SMP) ada dua tahap pelaksanaan yang akan dilakukan yakni tahap pertama adalah tahap pengembangan produk dan tahap kedua adalah tahap implementasi produk.

\section{Tahap Pengembangan Produk}

Pada tahap pertama dalam pengembangan produk, langkah yang diambil mengikuti langkah-langkah yang dikemukakan Rolston (1988: 138) yang meliputi: (1) pemilihan dan analisis kebutuhan yang sudah ada, (2) pembuatan prototipe, (3) formasilasi (penggunaan metode), (4) implementasi (coding), (5) evaluasi (testing dan validating), dan (6) perbaikan dan penyempurnaan.

Pada langkah problem revision dilakukan pemilihan dan analisis kebutuhan sistem yang sudah ada untuk pengumpulan informasi yang berfungsi untuk need assessment yang sudah ada sebagai desain penyusunan model, Berdasarkan informasi yang terkumpul dibuat prototipe perangkat lunak. Salah satu need assesment adalah prosedur kerja CAT menggunakan pohon segitiga keputusan. Dalam penelitian ini, bank soal yang digunakan adalah mata pelajaran Pendidikan Agama Islam (PAI) kelas VII jenjang pendidikan sekolah menegah pertama (SMP). Jumlah soal ada 180 butir soal sehingga cocok diaplikasikan dalam CAT metode pohon keputusan untuk level 18, dengan ketentuan 171 butir soal kategori baik masuk ke dalam sistem basis data utama yang akan dimunculkan oleh komputer dan hasil respons akan diestimasi menjadi kemampuan siswa, sedangkan 9 butir soal kategori kurang baik 
akan menjadi soal pembuka dalam CAT dan hasil respons tidak diestimasi sebagai kemampuan siswa.

Proses kembali ke pemilihan dan analisis kebutuhan jika dalam pengembangan prototipe ada kekurangan informasi. Langkah ini dinamakan problem revision. Pada langkah ini dilakukan terus menerus untuk memperoleh langkah yang representatif. Langkah akan berlanjut ke langkah berikutnya apabila ruang lingkup permasalahan yang diselesaikan telah terpenuhi.

Langkah kedua dalam perancangan logaritma dilakukan pembuatan sistematika kerja program perangkat lunak yang berdasarkan langkah pertama. Dengan langkah pada algoritma kemudian menerjemahkan algoritma ke dalam kode program. Pada langkah kedua ini akan kembali ke langkah perancangan algoritma apabila terdapat kode program yang tidak sesuai dengan algoritma, Langkah kedua ini dinamakan formalism revision. Proses ini juga bisa menuju ke langkah pertama bila terdapat informasi yang belum lengkap dan kurang sesuai dengan langkah pada langkah pertama. Proses pada langkah kedua ini akan menuju ke langkah ketiga bila target telah terpenuhi yaitu mendapatkan sebuah program yang mampu digunakan untuk menyelesaikan masalah.

Langkah ketiga pengujian perangkat lunak (debugging) yaitu langkah untuk menemukan kesalahan yang mungkin terjadi. Ada tiga kesalahan yang mungkin terjadi yaitu: (1) syntax error (kesalahan kalimat), (2), run time error (kesalahan saat dijalankan), dan (3), logic error (kesalahan fungsi dan hasil dari penalaran logika). Dari langkah ini dijadikan dasar proses perbaikan dan penyempurnaan program. Proses ini akan kembali ke pengujian program jika masih ada kesalahan yang menyebabkan program belum berfungsi seperti yang diharapkan. Langkah ketiga ini dinamakan evolutionari revision., Proses akan kembali ke langkah kedua (Formalism revision) jika ada kesalahan yang disebabkan oleh algoritma dan penulisan kode program yang belum sesuai dengan langkah ke dua. Bahkan akan ke langkah pertama (problem revision) apabila ada kesalahan algoritma dan kode program yang kurang sesuai yang disebabkan adanya algoritma dan kode program yang belum sesuai pada langkah pertama. 
Langkah-langkah ini adalah berbentuk siklus yang mengalami proses berulang jika pada langkah tertentu ada kesalahan, proses akan berulang pada bagian yang ditemukan kesalahan. Siklus akan bergerak terus menerus sehingga diperoleh perangkat lunak yang secara operasional dapat berfungsi sesuai dengan tujuan yang telah ditentukan.

\section{Tahap Implementasi Produk}

Tahap kedua adalah tahap implementasi produk, dalam tahap proses implementasi produk akan dilakukan implementasi CAT dalam situasi kelas yang sesungguhnya. Proses ini mengikuti langkah dari Borg \& Gall (2003: 774-776) sebagai berikut seperti Gambar 1 berikut ini.

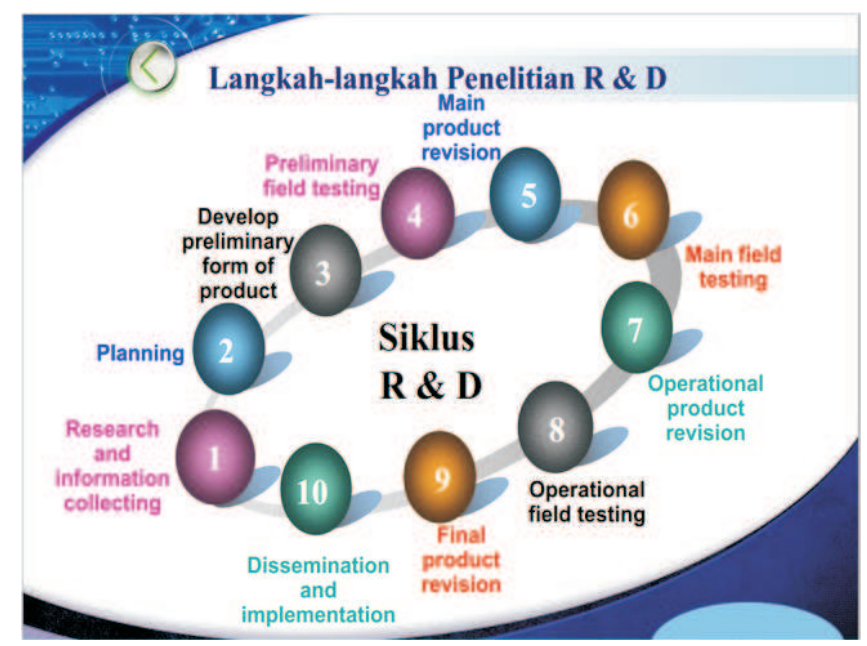

\section{Gambar 1}

Langkah-langkah penenlitian R \& D

Langkah: (1) research and information collecting yaitu melakukan review literatur, observasi kelas yang akan dijadikan implementasi dan mempersiapkan pelaksanaan; (2) planning yaitu mendefinisikan skill yang akan diamati, menentukan urutan-urutan tujuan yang hendak dicapai dan menguji; (3) devolop preliminary from product yaitu mempersiapkan materi, instruksional yang akan diberikan (memilih, mengorganisasi, mengemas materi, buku pegangan, peralatan evaluasi untuk mengukur keberhasilan tujuan; 
(4) preliminary field testing yaitu menggunakan produk dalam situasi kelas yang sebenarnya; (5) main product revision yaitu perbaikan product berdasarkan informasi hasil analisis data; (6) main field testing yaitu menggunakan produk hasil percobaan di kelas; (7) operational product revision yaitu melakukan kembali proses perbaikan dan penyempurnaan produk berdasarkan masukanmasukan dan analisis data yang terkumpul; (8) operational field testing yaitu menggukan kembali hasil produk yang telah diperbaiki; (9) final product revision yaitu memperbaiki produk akhir dengan diperoleh produk yang lebih sempurna; (10) desimination and implementation yaitu melaporkan hasil produk akhir yang telah disempurnakan dan disebarluaskan untuk lingkup yang lebih luas.

\section{Prosedur Pengembangan}

Prosedur pengembangan dalam penelitian ini dilakukan dalam jangka waktu tertentu. Tahap penelitian yang dilakukan dipilih essensial dan harus melewati sebuah rancangan produk yaitu: (1) analisis dan identifikasi kebutuhan, (2) perancangan desain sistem, (3) pembuatan produk (coding), (4) pengujian feasibilitas produk, (5) uji coba produk, (6) implementasi, dan (7) revisi produk.

Hasil pengujian bertujuan untuk menemukan kemampuan kinerja program sehingga hasilnya dapat direkomendasikan untuk dibakukan dan dipakai untuk mendukung peningkatan dalam lisensi testing/evaluasi/pengujian dan kualitas instrumen testing. Sekolah tempat implementasi CAT dipilih dengan teknik purposive sampling, yakni sekolah yang memiliki laboratorium komputer dan dilengkapi dengan jaringan LAN (Local Area Network). Tempat implementasi dilakukan di Sekolah Menengah Pertama Negeri (SMP N) 1 kota Salatiga yang memiliki laboratorium komputer dengan dilengkapi jaringan LAN.

Dalam desain uji coba ini dilakukan untuk mengetahui kemampuan dan kelayakan software CAT. Proses pengujian dilakukan menggunakan bantuan seperangkat unit komputer dan dilaksanakan di laboratorium komputer. Dalam pelaksanaanya setiap siswa akan diminta oleh komputer beberapa informasi antara lain: nama login, email, nama depan, nama belakang, tingkat pengguna, dan password. Kemudian peserta membuat Account yang berisi user 
dan password. Setelah siswa login maka komputer akan menampilkan soal yang diambil dari bank soal dalam CAT yaitu bank soal PAI kelas VII jenjang pendidikan sekolah menegah pertama (SMP).

Hasil respons siswa diberi nilai 1 jika jawaban benar dan diberi nilai 0 jika jawaban salah, Hasil kemampuan (è) kemudian dikonversi ke dalam skor dengan rentang $0-100$. Perhitungan konversi skor seperti pada Tabel 3 berikut.

Tabel 3

Konversi Kemampuan (è) menjadi skor (y)

\begin{tabular}{lccc}
\hline \multirow{2}{*}{ Jenis } & \multicolumn{3}{c}{ Ketuntasan belajar } \\
\cline { 2 - 4 } & Belum tuntas & Tuntas baik & Tuntas sangat baik \\
\hline Kemampuan $(\theta)$ & $-4,00 \leqslant \theta<-1,00$ & $-1,00 \leqslant \theta<1,00$ & $1,00 \leqslant \theta \leqslant 4,00$ \\
Penilaian Acuan Normal $(\mathrm{x})$ & $0,0 \leqslant \mathrm{x}<\mathrm{M}-0,5 \mathrm{~s}$ & $\mathrm{M}-0,5 \mathrm{~s} \leqslant \mathrm{x}<\mathrm{M}+1,5 \mathrm{~s}$ & $\mathrm{M}+1,5 \mathrm{~s} \leqslant \mathrm{x} \leqslant 100$ \\
Skor skala $0-100$ & $0,0 \leqslant \mathrm{y}<37,0$ & $37,0 \leqslant \mathrm{y}<62,5$ & $62,5 \leqslant \mathrm{y} \leqslant 100$ \\
\hline
\end{tabular}

Keterangan: $\quad \mathrm{N}=$ Nilai

$$
\begin{aligned}
& M=\text { Rerata } \\
& y=12,5 \text { è }+50
\end{aligned}
$$$$
\mathrm{s}=\text { Simpangan baku }
$$

Penelitian ini dalam pelaksanaannya dilakukan di: (a) laboratorium komputer STAIN Salatiga, untuk proses pengembangan (development) software CAT; (b) laboratorium komputer STAIN Salatiga untuk uji coba pengguna guru PAI dan Laboratorium komputer SMP N 1 kota Salatiga untuk uji coba pengguna siswa sebagai tempat untuk implementasi/research produk software CAT dalam situasi yang sebenarnya; (c) waktu penelitian, dilakukan pada bulan Januari 2012 sampai Mei 2012 untuk pembuatan software CAT, Bulan Juni 2012 sampai Juli 2012 untuk implementasi atau pengujian software CAT.

Subyek yang digunakan dalam penelitian untuk untuk uji coba adalah: (a) 8 guru PAI untuk proses penggalian informasi dan identifikasi kebutuhan sistem yang diperlukan dalam software CAT dan juga untuk memperoleh informasi mengenai pemilihan materi tes uji coba; (b) pakar IT untuk mengetahui kelayakan software CAT, dan (c) 20 siswa kelas VIII SMP Negeri 1 kota Salatiga dalam rangka uji fungsionalitas dan unjuk kerja program software CAT dalam membuat rekam medik pembelajaran (RMP) untuk mendiagnosis kemamapuan siswa. Instrument penelitian yang digunakan untuk mengumpulkan data dalam penelitian seperti Tabel 4 berikut. 


\section{Tabel 4 Instrumen penelitian}

\begin{tabular}{|c|c|c|c|c|c|c|}
\hline \multirow{2}{*}{ No } & \multirow{2}{*}{ Pernyataan } & \multicolumn{5}{|c|}{ Skor } \\
\hline & & 1 & 2 & 3 & 4 & 5 \\
\hline \multicolumn{7}{|c|}{ pek Performasi Penggunaan } \\
\hline & Kelengkapan fasilitas yang mendukung operasional & 1 & 2 & 3 & 4 & 5 \\
\hline 2 & Kelengkapan menu untuk mendukung operasional & 1 & 2 & 3 & 4 & 5 \\
\hline 3 & Pemakaian bahasa yang digunakan pada program & 1 & 2 & 3 & 4 & 5 \\
\hline 4 & Penggunaan navigasi/pengarah pada bagian yang penting & 1 & 2 & 3 & 4 & 5 \\
\hline \multicolumn{7}{|c|}{ Aspek Performansi Tampilan } \\
\hline 5 & Ketepatan ukuran teks yang digunakan & 1 & 2 & 3 & 4 & 5 \\
\hline 6 & Ketepatan bentuk teks yang digunakan & 1 & 2 & 3 & 4 & 5 \\
\hline 7 & Ketepatan warna teks yang digunakan & 1 & 2 & 3 & 4 & 5 \\
\hline 8 & Ketepatan warna teks dengan background yang digunakan & 1 & 2 & 3 & 4 & 5 \\
\hline 9 & Kualitas gambar yang digunakan untuk mendukung tampilan & 1 & 2 & 3 & 4 & 5 \\
\hline \multicolumn{7}{|l|}{ C. } \\
\hline 10 & $\begin{array}{l}\text { Relevansi soal-soal dengan materi/pokok bahasan PAI seperti yang } \\
\text { tertera dalam kisi-kisi pembuatan soal }\end{array}$ & 1 & 2 & 3 & 4 & 5 \\
\hline 11 & $\begin{array}{l}\text { Relevansi soal -soal dengan standar kompetensi yang hendak } \\
\text { diukurseperti yang tertera dalam kisi-kisi pembuatan soal PAI }\end{array}$ & 1 & 2 & 3 & 4 & 5 \\
\hline 12 & $\begin{array}{l}\text { Relevansi soal-soal dengan kompetensi dasar yang hendak diukur } \\
\text { seperti yang tertera dalam kisi-kisi pembuata n soal PAI }\end{array}$ & 1 & 2 & 3 & 4 & 5 \\
\hline 13 & $\begin{array}{l}\text { Relevansi n soal-soal dengan indikator yang hendak diukur seperti } \\
\text { yang tertera dalam kisi-kisi pembuatan soal PAI }\end{array}$ & 1 & 2 & 3 & 4 & 5 \\
\hline 14 & $\begin{array}{l}\text { Relevansi soal-soal dengan kurikulum acuannya (Kurikulum } \\
\text { Jenjang Satuan Pendidikan) yang hendak diukur seperti yang } \\
\text { tertera dalam kisi-kisi pembuatan soal PAI }\end{array}$ & 1 & 2 & 3 & 4 & 5 \\
\hline 15 & Relevansi pilihan jawaban dengan butir soal PAI yang diujikan & 1 & 2 & 3 & 4 & 5 \\
\hline 16 & Relevansi variasi materi tes dengan pokok bahasan PAI & 1 & 2 & 3 & 4 & 5 \\
\hline \multicolumn{7}{|c|}{ D. $A$} \\
\hline 17 & $\begin{array}{l}\text { Penggunaan program CAT dapat membantu untuk proses } \\
\text { pengujian }\end{array}$ & 1 & 2 & 3 & 4 & 5 \\
\hline 18 & Penggunaan program CAT dapat memotivasi siswa untuk b & 1 & 2 & 3 & 4 & 5 \\
\hline 19 & $\begin{array}{l}\text { Program CAT membantu guru mempermudah administrasi data } \\
\text { nilai }\end{array}$ & 1 & 2 & 3 & 4 & 5 \\
\hline
\end{tabular}

(ket: 1= sangat jelek; 2=jelek; 3=biasa; 4= bagus; 5=sangat bagus)

Teknik analisis data yang digunakan dalam pengembangan CAT ini adalah teknik analisis deskriptif evaluatif dan teknik analisis deskriptif kuantitatif. Kedua teknik ini digunakan karena dalam penelitian ini tidak melakukan pengujian hipotesis. Penelitian ini akan menguji kelayakan produk yang digunakan untuk mengevaluasi kemampuan peserta menggunakan CAT yang menggunakan metode pohon segitiga keputusan.

Teknik analisis deskriptif evaluatif dilakukan untuk menentukan kelayakan. kemampuan dan efektifitas kerja produk dalam mengukur kemampuan siswa. Teknik analisis deskriptif kuantitatif dilakukan untuk mengetahui gambaran tingkat kemampuan siswa yang diukur dengan tes terkomputerisasi menggunakan metode pohon segitiga keputusan. 


\section{Hasil Validasi Software CAT PAI}

Hasil validasi penelitian disajikan dalam tabel 5 berikut.

Tabel 5.

Hasil Validasi Software CAT

\begin{tabular}{lllccl}
\hline No & \multirow{2}{*}{ Responden } & \multicolumn{1}{c}{ Aspek } & $\begin{array}{c}\text { Grand } \\
\text { mean }\end{array}$ & $\hat{p}_{p *}^{2}$ & \multicolumn{1}{c}{ Ket } \\
\hline 1 & Pakar & Performasi Penggunaan & 4,0 & 0,73 & Tinggi \\
& & Performansi Tampilan & 3,9 & 0,48 & Cukup tinggi \\
& & Relevansi Materi Tes & 4,3 & 0,70 & Tinggi \\
\multirow{2}{*}{2} & \multirow{2}{*}{ Kelompok kecil } & Kemanfaatan & 4,0 & 0,75 & Tinggi \\
& & Performasi Penggunaan & 3,7 & 0,78 & Tinggi \\
& & Performansi Tampilan & 3,9 & 0,7 & Tinggi \\
& & Relevansi Materi Tes & 3,9 & 0,70 & Tinggi \\
\multirow{4}{*}{3} & \multirow{2}{*}{ Kelompok besar } & Kemanfaatan & 4,0 & 0,82 & Tinggi \\
& & Performasi Penggunaan & 4,5 & 0,87 & Tinggi \\
& & Performansi Tampilan & 4,2 & 0,74 & Tinggi \\
& & Relevansi Materi Tes & 3,8 & 0,85 & Tinggi \\
& & Kemanfaatan & 4,0 & 0,63 & Cukup tinggi \\
\hline
\end{tabular}

Berdasar tabel 5 di atas menunjukkan bahwa pesponden memiliki konsistensi yang cukup tinggi dan tinggi dalam memvalidasi software Computerized Adaptive Testing Pendidikan Agama Islam (CAT PAI). Nilai rata-rata grand mean semua aspek yakni: 4,02, sedangkan nilai rata-rata nilai $\hat{p}_{p^{*}}^{2}$ yakni: 0,73 , sehingga software CAT PAI ini bisa digunakan untuk penelitian.

\section{Hasil Tampilan awal CAT PAI}

Hasil tampilan awal CAT PAI akan tampil sesaat setelah program CAT dipanggil (dijalankan). Desain tampilan awal terdiri dari: Teks pertama berbunyi “COMPUTERIZED ADAPTIVE TESTING (CAT)" yang diketik dengan huruf kapital semua dan berwarna putih. Tes kedua berbunyi "Pengujian Hasil Belajar dan Penilaian Pendidikan Berbantuan Komputer untuk mata palajaran Pendidikan Agama Islam (PAI) Tingkat pendidikan SMP/MTs kelas VII" juga berwarna putih. Teks login, pengguna, nama pengembang, foto, dan SEKOLAH TINGGI AGAMA ISLAM (STAIN) SALATIGA 2012. Dibelakang ketiga teks terdapat warna backround biru. Hasil tampilan awal CAT PAI disajikan dalam Gambar 2 berikut ini 


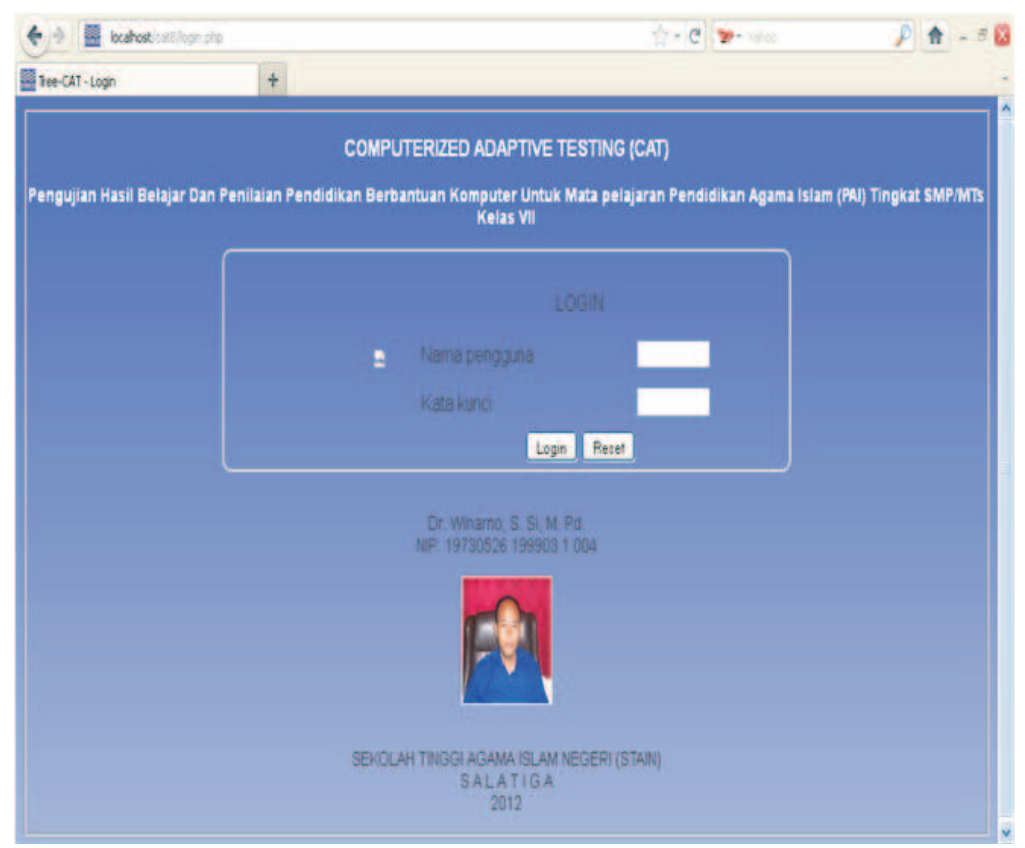

\section{Gambar 2 \\ Tampilan awal CAT}

\section{Contoh soal dalam CAT PAI}

Contoh soal dalam CAT PAI adalah pada bagian atas berisi soal dengan warna biru dan stem (opsi jawaban) di bawah soal dengan warna hitam. Penggunaan warna yang berbeda ini untuk membedakan antara soal dan stem (opsi jawaban). Selain itu juga ditampilkan waktu yang tersedia, jika waktu telah menuju nol (0) maka waktu habis. Jika siswa tidak menjawab maka komputer akan menampilkan soal berikutnya dan soal tadi disimpulkan salah karena siswa tidak menjawab karena waktu habis. Langkah menjawab bagi siswa adalah di"klik" pilihan jawaban yang benar kemudian di"klik" ikon jawab. Contoh soal dalam CAT PAI disajikan dalam Gambar 3 berikut ini 


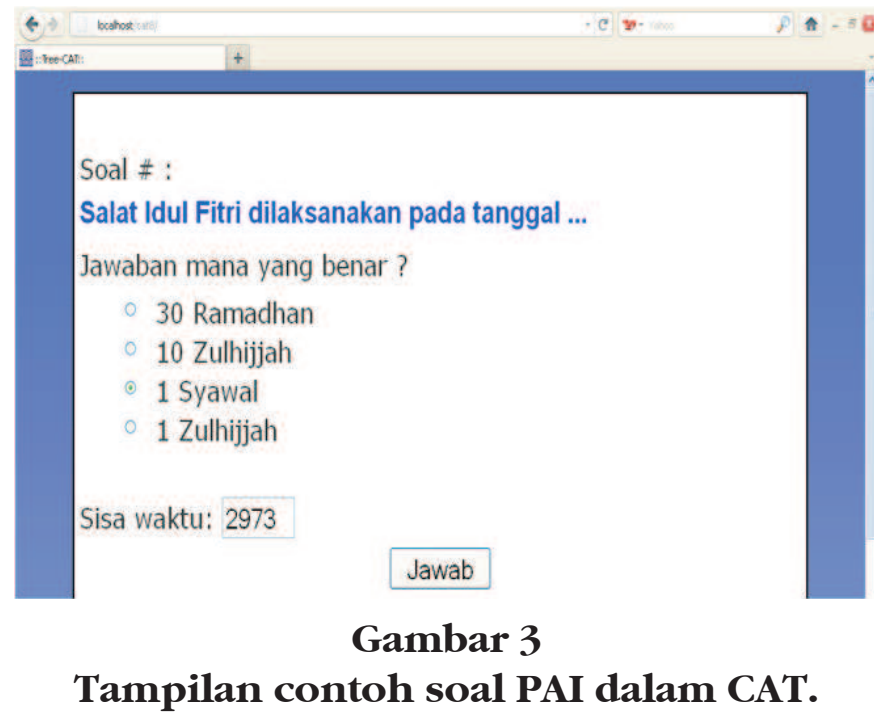

\section{Analisis}

\section{Hasil Rekam Medik Pembelajaran (RMP) CAT PAI}

Dalam CAT PAI yang dikembangkan, penentuan standar kompetensi (SK) dan kompetensi dasar (KD) adalah sebagai berikut: (1) SK nomor 1 tentang Al Qur'an dan Hadits, (2) SK nomor 2 tentang Aqidah dan Akhlak, (3) SK nomor 3 tentang Fiqih, dan (5) SK nomor 4 tentang Tarikh dan Kebudayaan Islam. Dalam mendiagnosis kemampuan PAI maka dilihat dari respon benar-salah pada SK dan KD. Apabila siswa menjawab salah pada SK dan KD tertentu maka siswa tersebut belum menguasai dan apabila siswa menjawab benar pada SK dan KD tertentu maka siswa tersebut sudah paham

Tampilan hasil rekam medik pembelajaran PAI terdiri atas Soal ke-, ID, nomor pertanyaan, keterangan benar/salah, waktu, tingkat kesukaran, daya beda, tingkat menebak, standar kompetensi (SK), kompetensi dasar (KD), indikator, dan theta. Rekam medik pembelajaran (RMP) ini berisi hasil respons (benar atau salah) yang akan digunakan untuk mendiagnosis kemampuan siswa. Siswa yang paham materi pelajaran PAI maka mereka menjawab benar dan waktu yang singkat tetapi siswa yang tidak paham materi pelajaran PAI cenderung mengerjakan soal salah dan waktu yang cepat. Hasil RMP CAT PAI disajikan pada Gambar 4 di bawah ini. 


\begin{tabular}{|c|c|c|c|c|c|c|c|c|c|c|c|}
\hline $\begin{array}{l}\text { Soal } \\
\text { Ke: }\end{array}$ & Id & $\begin{array}{l}\text { No } \\
\text { Pertanyaan }\end{array}$ & Benar/5alah & $\begin{array}{l}\text { Waktu } \\
\text { (detik) }\end{array}$ & TK & $\mathrm{DB}$ & $T M$ & SK & KD & Indikator & Theta \\
\hline 1 & 36 & 12 & benar & 29 & -1.807 & 0.676 & 0.247 & 1 & 1 & 1 & -1.5 \\
\hline 2 & 110 & 86 & stikh & 36 & -1.574 & 0.52 & 0.244 & 2 & 1 & 2 & -1.6 \\
\hline 3 & 168 & 144 & benar & 0 & -1.575 & 1.176 & 0.262 & 3 & 3 & 2 & $-1,4$ \\
\hline 4 & 167 & 143 & whan & 49 & -1.318 & 1.375 & 0.195 & 4 & 1 & 7 & -1.9 \\
\hline 5 & 50 & 26 & benar & 10 & -1.32 & 0.912 & 0.266 & 5 & 5 & 1 & .18 \\
\hline 6 & 162 & 138 & stah & 28 & -1.178 & 1.341 & 0.162 & 6 & 3 & 3 & -1.9 \\
\hline 7 & 83 & 59 & stah & 28 & -1.179 & 1.416 & 0.169 & 1 & 2 & 2 & 2 \\
\hline 8 & 72 & 48 & benar & 28 & -1.179 & 1.09 & 0.269 & 2 & 4 & 5 & -1.9 \\
\hline 9 & 103 & 79 & benar & 18 & -1.038 & 0.708 & 0.454 & 3 & 1 & 6 & -1.8 \\
\hline 10 & 45 & 21 & benar & 48 & -0.84 & 1.75 & 0.485 & 4 & 4 & 1 & -0.4 \\
\hline 11 & 46 & 22 & benar & 38 & -0.731 & 0.882 & 0.214 & 5 & 3 & 2 & .0 .4 \\
\hline 12 & 52 & 28 & benar & 51 & -0.467 & 0.966 & 0.28 & 6 & 2 & 1 & -0.4 \\
\hline 13 & 185 & 161 & benar & 21 & -0.346 & 0.909 & 0.158 & 1 & 2 & 2 & -0.4 \\
\hline 14 & 92 & 68 & Itah & 10 & -0.062 & 1.56 & 0.129 & 2 & 3 & 1 & -0.6 \\
\hline 15 & 120 & 96 & benar & 22 & -0.085 & 0.619 & 0.151 & 3 & 3 & 1 & -0.6 \\
\hline 16 & 31 & 7 & benar & 29 & 0.15 & 0.919 & 0.217 & 4 & 3 & 4 & .0 .5 \\
\hline 17 & 108 & 84 & benar & 28 & 0.303 & 0.537 & 0.372 & 5 & 4 & 1 & -0.5 \\
\hline 18 & 205 & 181 & benar & 26 & 0.434 & 0.749 & 0.316 & 6 & 1 & 7 & -0.5 \\
\hline
\end{tabular}

\section{Gambar 4 \\ Tampilan hasil rekam medik pembelajaran CAT PAI}

Pada Gambar 4 di atas dari hasil rekam medik pembelajaran bisa disimpulkan bahwa untuk SK nomor 1 tentang Al Qur'an dan Hadits untuk soal dengan tingkat kesukaran sedang dan tinggi siswa ini bisa menjawab dengan benar, sehingga bisa disimpulkan bahwa untuk materi Al Qur'an dan Hadits sudah paham. Pada SK nomor 2 tentang Aqidah dan Akhlak untuk soal dengan tingkat kesukaran yang sedang dan tinggi menjawab salah maka bisa disimpulkan bahwa siswa ini untuk materi Aqidah dan Akhlak belum paham sehingga perlu treatment tambahan.

Pada SK nomor 3 tentang Fiqih untuk soal dengan tingkat kesukaran sedang dan tinggi bisa menjawab dengan benar maka bisa disimpulkan bahwa siswa ini untuk materi tentang Fiqih sudah paham. Pada SK nomor 4 tentang Tarikh dan Kebudayaan Islam untuk soal dengan tingkat kesukaran sedang menjawab salah sedangkan untuk soal dengan tingkat kesukaran tinggi menjawab benar maka disimpulkan setelah diberi soal tentang Tarikh dan Kebudayaan Islam pada soal pertama maka siswa ini bisa paham karena soal kedua dengan tingkat kesukaran tinggi justru bisa menjawab dengan benar. 


\section{Hasil Pengujian terhadap 20 Siswa}

Pengujian beta digunakan untuk mengetahui kemampuan kerja program CAT PAI dalam memprediksi kemampuan siswa melalui butir-butir tes yang dikerjakan. Untuk menjaga dari hal hal yang tidak diinginkan, nama siswa diwakilkan dengan atribut "Siswa kc-i". Hasil kerja program yang diujikan kepada sejumlah 20 siswa dalam uji coba disajikan dalam Tabel 2 berikut.

Tabel 2

Hasil uji coba siswa

\begin{tabular}{cccccl}
\hline No & Siswa ke- & Theta & Nilai & NUM PAI & Keterangan \\
\hline 1 & Siswa ke-1 & $-0,5$ & 43,75 & 70 & Tuntas baik \\
2 & Siswa ke-2 & 0,1 & 51,25 & 95 & Tuntas baik \\
3 & Siswa ke-3 & $-0,2$ & 47,5 & 73 & Tuntas baik \\
4 & Siswa ke-4 & $-1,5$ & 31,25 & 60 & Tuntas baik \\
5 & Siswa ke-5 & $-0,7$ & 41,25 & 68 & Tuntas baik \\
6 & Siswa ke-6 & $-0,9$ & 38,75 & 70 & Tuntas baik \\
7 & Siswa ke-7 & 1,5 & 68,75 & 97 & Tuntas sangat baik \\
8 & Siswa ke-8 & $-0,2$ & 47,5 & 78 & Tuntas baik \\
9 & Siswa ke-9 & 0 & 50 & 90 & Tuntas baik \\
10 & Siswa ke-10 & $-0,8$ & 40 & 63 & Tuntas baik \\
11 & Siswa ke-11 & $-0,6$ & 42,5 & 83 & Tuntas baik \\
12 & Siswa ke-12 & $-0,7$ & 41,25 & 88 & Tuntas baik \\
13 & Siswake-13 & $-0,6$ & 42,5 & 88 & Tuntas baik \\
14 & Siswa ke-14 & 0 & 50 & 95 & Tuntas baik \\
15 & Siswa ke-15 & 1,4 & 67,5 & 100 & Tuntas sangat baik \\
16 & Siswa ke-16 & 0,1 & 51,25 & 90 & Tuntas baik \\
17 & Siswa ke-17 & 0,2 & 52,5 & 80 & Tuntas baik \\
18 & Siswa ke-18 & $-0,9$ & 38,75 & 80 & Tuntas baik \\
19 & Siswa ke-19 & $-0,5$ & 43,75 & 95 & Tuntas baik \\
20 & Siswa ke-20 & $-0,1$ & 48,75 & 78 & Tuntas baik \\
\hline
\end{tabular}

Hasil pengujian dalam pengujian sebagai berikut: (1) ratarata peserta ujian mendapat 15 butir soal PAI, butir siswa mendapatkan soal paling sedikit sebanyak 13 butir soal dan siswa mendapatkan soal terbanyak ada 18 butir soal; (2) kemampuan peserta terendah adalah $-1,5$ untuk siswa uji coba ke-10, sedangkan kemampuan peserta tertinggi adalah 1,5 untuk siswa uji coba ke46; rata-rata kemampuan siswa adalah -1; dan (3) 18 siswa tuntas baik dan 2 siswa tuntas dengan baik. 
Berdasar hasil analisis data dari ke-20 siswa menunjukkan bahwa sistem inferensi yang dibangun pada program CAT telah berhasil dengan baik, tepat, akurat, dan sesuai dengan kemampuan peserta dalam memilih butir-butir tes yang yang tepat dan sesuai dengan kemampuan peserta, Dalam hal itu, peserta dengan kemampuan tinggi menerima butir-butir tes dengan tingkat kesulitan tinggi. Peserta dengan kernampuan sedang menerima butir-butir tes dengan tingkat kesulitan sedang. Peserta dengan kemampuan rendah menerima butir-butir tes dengan tingkat kesulitan rendah. Disisi lain banyak butir yang diterima peserta antara yang satu dengan yang lain beragam (tidak sama). Peserta dengan kemampuan tinggi atau peserta dengan kemampuan rendah menerima banyak butir lebih sedikit dibandingkan dengan peserta berkemampuan sedang. Hal ini menunjukkan bahwa CAT PAI yang dikembanhkan berhasil dengan baik dengan kemampuan peserta (adaptif).

Ketepatan dan keakuratan sistem inferensi model CAT dalam memilih butir-butir tes yang sesuai dengan kemampuan siswa terbukti dengan hasil bahwa siswa memiliki nilai ulangan murni (NUM) PAI tinggi di sekolah juga memiliki kemampuan tinggi, siswa memiliki NUM PAI sedang di sekolah memiliki kemampuan sedang, dan siswa memiliki NUM PAI rendah di sekolah juga memiliki kemampuan rendah. Nilai korelasi (r) antara hasil estimasi kemampuan pada CAT dengan NUM PAI di sekolah siswa cukup tinggi yakni $r=0,69$

\section{Kesimpulan}

Berdasarkan hasil penelitian dan pembahasan dapat diambil kesimpulan sebagai berikut:

1. Software Computerized Adaptive Testing mata pelajaran Pendidikan Agama Islam (CAT PAI) kelas VII jenjang pendidikan sekolah menegah pertama (SMP) yang dikembangkan berbasis jaringan internet (web based) dan menggunakan bahasa pemrograman PHP dan sistem basis data menggunakan My SQL. Hasil rekam medik pembelajaran terdiri atas komponen: soal ke-, ID, nomor pertanyaan, keterangan benar/salah, waktu, tingkat kesukaran, daya beda, tingkat menebak, standar kompetensi (SK), kompetensi dasar (KD), indikator, dan theta. 
2. Ketepatan dan keakuratan sistem inferensi model CAT dalam memilih butir-butir tes yang sesuai dengan kemampuan siswa diwujudkan dari hasil uji coba beta (siswa) dengan hasil bahwa siswa yang memiliki nilai ulangan murni (NUM) PAI tinggi di sekolah juga memiliki $\mathrm{k}$ emampuan (è) tinggi, siswa yang memiliki nilai ulangan murni (NUM) PAI sedang di sekolah juga memiliki kemampuan (è) sedang, dan siswa yang memiliki nilai ulangan murni (NUM) PAI rendah di sekolah juga memiliki kemampuan (è) rendah, Nilai korelasi (r) antara hasil estimasi kemampuan (è) pada CAT dengan nilai ulangan murni (NUM) PAI di sekolah siswa cukup tinggi yakni $r=0,69$.

\section{Daftar Pustaka}

Borg. W.R. \& Gall. M.D. 2003. Education research an introduction. New York: Von Hoffman Press. Inc.

Hambleton. R.K. \& Swaminathan. H. 1985. Item response theory. Boston. MA: Kluwer Inc.

Lord. F.M. 1980. Applications of item response theory to practical testing problems. Hillsdale. NJ : Erlbaum.

Majid, Abdul. 2005. Pendidikan Agama Islam Berbasis Kompetensi. Bandung: PT Remaja Rosdakarya.

Masters. N.G. \& Keeves. P.J. 1999. Advances in measurement in educational research and assesment. New York: Pergamon Press.

Mills. C.N. 1999. Development and introduction of a computere adaptive graduate record examinations general test. Marwah. NJ: Lawrence Earlbaum Associates Publishers.

Phankokkruad. M. \& Woraratpanya. K. 2008. An automated decision system for computer adaptive testing using genetic algorithms. Ninth ACIS International Conference on Engineering. Artificial Intellegence. Networking. and Parallel. 655-660

Rolston. D.W. 1988. Principles of artificial intelligence and expert systems development. Singapore: McGraw Hill Book. Co.

Wainer. H. 1990. Computerized adaptive testing : A primer. Hillsdale. NJ: Lawrence Erlbaum Associates. Publisher.

Weiss. D.J. 2004. Computerized adaptive testing for effective and efficient measurement in counseling and education. Measurement and Evaluation in Counseling and Development, Vol. VII, No: 37: 70-75. 